\title{
Dental Pulp Vitality and Dentin Deposition in Injured, Immature Teeth of Dogs
}

\author{
I. CAPÍK, V. LEDECKÝ, A. ŠEVČÍK, *Ž. KUZEVIČ \\ Department of Surgery, University of Veterinary Medicine, Košice, Slovakia \\ *Department BERG, Technical University, Košice, Slovakia
}

Received September 13, 2002

Accepted September 22, 2003

\begin{abstract}
Capík I., V. Ledecký, A. Ševčík, Ž. Kuzevič: Dental Pulp Vitality and Dentin Deposition in Injured, Immature Teeth of Dogs Acta Vet. Brno 2003, 72: 383-389.

This study was conducted to observe the reaction of dental pulp after tooth fractures in dogs in the first two years of age, at the time of the most intensive dentin production. The aim of the study was to compare the ability of dental pulp to survive and continue its dentin production during the main time of maturation.

Twelve dogs were used in the study. Group 1 consisted of six dogs, aged $12 \pm 1$ months, and Group 2 consisted of six dogs, aged $20 \pm 1$ months. All procedures were carried out in anaesthetized animals. Seven teeth of each dog were fractured avoiding concussion - two incisors, two canines, and three premolars (third, fourth upper and third lower). The dental pulp was exposed by amputation of the coronal third of the crowns using a high-speed dental bur and extraction forceps, avoiding concussion of the dental pulp. Clinical and radiographic examination of the teeth was performed at monthly intervals for one year. All radiographs taken in the $1^{\text {st }}, 5^{\text {th }}$ and $10^{\text {th }}$ month of the study were processed and evaluated by computer programs.

The results showed significant differences (F-test, $P \leq 0.01$ ) in the viability of dental pulp between both groups despite relatively small difference in age. At the end of study the teeth that remained viable for 10 months in both groups of dogs had the same width of root canals despite the difference in the age of dogs and initial width of root canals.

The viability of dental pulps seemed to be influenced mainly by the degree of concussion shock caused by trauma and tooth localization in the mouth cavity.

Dog, age, tooth fracture, dental pulp, dentin deposition, vitality
\end{abstract}

Dental mesenchymal cells give rise to odontoblasts during tooth development and odontoblast-like cells during pulp repair in adult teeth. It is well recognized that odontoblast differentiation during primary dentinogenesis is controlled by the inner dental epithelium through basement membrane-mediated interactions (Ruch 1985).

Mature cells in dental pulp are considered to be capable of differentiation into odontoblasts, as they are able to respond to injury by producing reparative dentin in vivo (Heriteir et al. 1989; Fitzgerald et al. 1990) as well as forming hard tissue in vitro (Bövier et al. 1990; Nakashima 1991).

Whenever the pulp is exposed, treatment success depends on the size and time of the exposure, the age of the animal and the healing potential of the dental pulp (Duell 1995). Following pulp exposure, the degree of pulp infection and inflammation is difficult to determine, as it depends on the intensity of the traumatic insult, the extent of bacterial contamination, and the duration of time from exposure to treatment (Wiggs and Lobpris e 1997).

Endodontic treatment, such as vital pulpotomy, is indicated for recent fractures to preserve the dental pulp healthy.

Ideally, tooth fracture with pulp exposure should be treated by partial pulpectomy as soon after the trauma as practical. Numerous studies (Cvek 1982; Heide 1980; Heide and

Address for correspondence:

MVDr. Igor Capík Ph.D.

Univerzita veterinárskeho lekárstva

Katedra chirurgie, ortopédie a rtg
Komenského 73, 041 Košice, Slovenská Republika

Phone: +421 556337832

E-mail: capik@uvm.sk 
Kerekes 1986) indicate that the depth of pulp inflammation does not exceed 2-3 mm from the exposed surface for up to seven days following traumatic exposure. There are no strict rules regarding vital pulpotomy treatment and pulp exposure in veterinary dentistry.

Therefore treatment by direct pulp capping may still be successful when performed days or weeks after the trauma (Heide and Kerekes 1987).

Dentin bridge formation may also occur following the use of proper materials and even if exposed pulps are left open to the oral environment in germ-free animals (Kakehashi et al. 1965). Healing has also been reported to occur if inflamed pulps are capped, either occasionally (Tronstad and Mjör 1972; Langeland et al. 1973) or consistently (Cox and Bergenholtz 1986)

Injuries of the dental pulp include mainly traumatic injuries due to concussion shock and infection. Prevalence of dental fractures is also influenced by the age and behaviour of dogs. Most frequently injured dogs are those 1 and 2 years of age, the most prevalent area of injuries in intraspecies confrontations being their head region (Baranyiová et al. 2003) with possible dental fractures.

The purpose of this study was to determine radiologically the vitality of exposed dental pulp in maturing teeth of dogs and its influence on dentin deposition.

\section{Materials and Methods}

This study was approved by the Ethical Committee of the University of Veterinary Medicine in Košice. Two groups of healthy mongrel dogs kept under standard conditions were used in the study. Group 1 consisted of six dogs, aged $12 \pm 1$ months, Group 2 consisted of six dogs, aged $20 \pm 1$ months. The animals were anaesthetised throughout all experimental procedures. The anaesthesia was induced by intravenous administration of $0.5 \mathrm{mg} \cdot \mathrm{kg}^{-}$ ${ }^{1}$ body weight of diazepam and $4 \mathrm{mg} \cdot \mathrm{kg}^{-1}$ of ketamine, followed by $1-2 \%$ isoflurane for maintenance of anaesthesia. Seven teeth of each dog were fractured avoiding concussion - 2 incisors, 2 canines, 3 premolars (third, fourth upper and third lower). Within the first week after trauma NSAID (flunixin meglumine $1.1 \mathrm{mg} \cdot \mathrm{kg}^{-1}$ i.m.) was administered. The dental pulp was exposed by amputation of the coronal third of the crowns using a high-speed dental bur and extraction forceps, avoiding concussion of the dental pulp. Clinical and radiographic examination of the teeth was performed monthly for one year.

All radiographs taken on the $1^{\text {st }}, 5^{\text {th }}$ and $10^{\text {th }}$ month of the study were processed and evaluated by the following computer programs:

- scanning: Presto! Page Manager

- arrangement: Photo Editor

measurement: ArcView GIS 3.2

The measurements were done at the Technical University in Košice. The individual groups of teeth were measured at the same level, each tooth three times, and mean values were calculated. The measurements were taken at the neck of the incisors and maxillary canines. On maxillary premolars the distal roots were measured at the level connecting CEJ and root furcation. Mandibular canines were measured at the level of mesial surface of the first mandibular premolars and third mandibular premolars at the level of alveolar crest on the distal root.

Viability of dental pulp in both groups of dogs was statistically evaluated using Fischer's test. Viability of tooth groups under study and dentin deposition in fractured teeth were analyzed as well.

\section{Results}

Differences in viability of dental pulp of dogs between the experimental groups

The viability of dental pulp differed significantly (F-test, $P \leq 0.01$ ) between the two groups observed despite a relatively small age difference (Fig. 1). Out of 42 teeth observed in Group 1, 25 tooth pulps (59.5\%) were vital after 5 months while in Group 2 vitality was only preserved in 15 teeth $(35.7 \%)$. The two groups differed by vitality of 10 teeth, i. e. almost one quarter of all teeth observed (24\%).

After 10 months, the difference between the two groups decreased to 7 teeth, i. e. almost $17 \%$. Fig. 1 also shows typical difference in the number of teeth with vital pulps. While Group 1 showed an almost uniform necrotization of dental pulp throughout the study, a marked 
decrease in the number of vital pulp (by 1.5) was observed in Group 2 during the first month of study. During the remaining 9 months the decrease in Group 2 resembled that observed in Group 1.

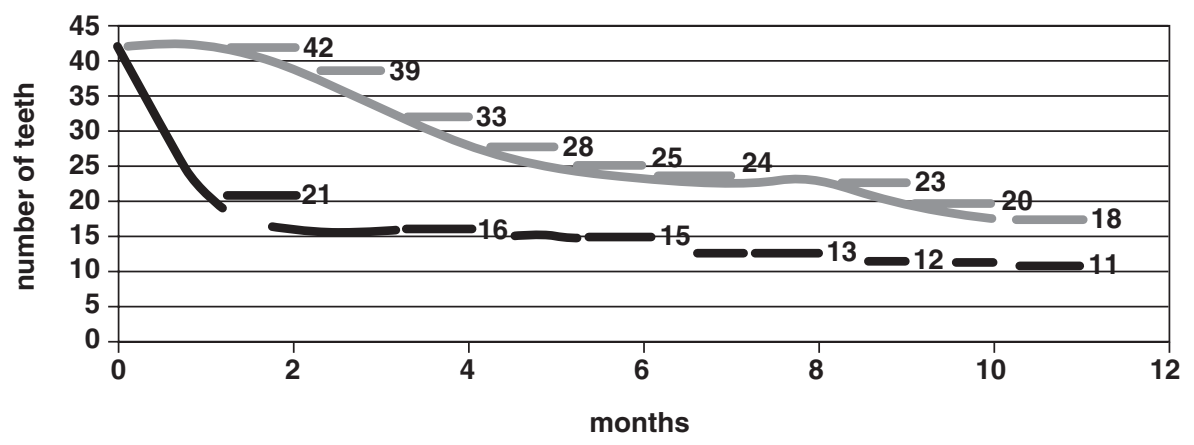

Fig. 1. Survival of dental pulps in both groups

Viability of different tooth groups

In both groups of dogs the highest viability of dental pulp was observed with premolar teeth, followed by canines, and incisors (Fig. 2).

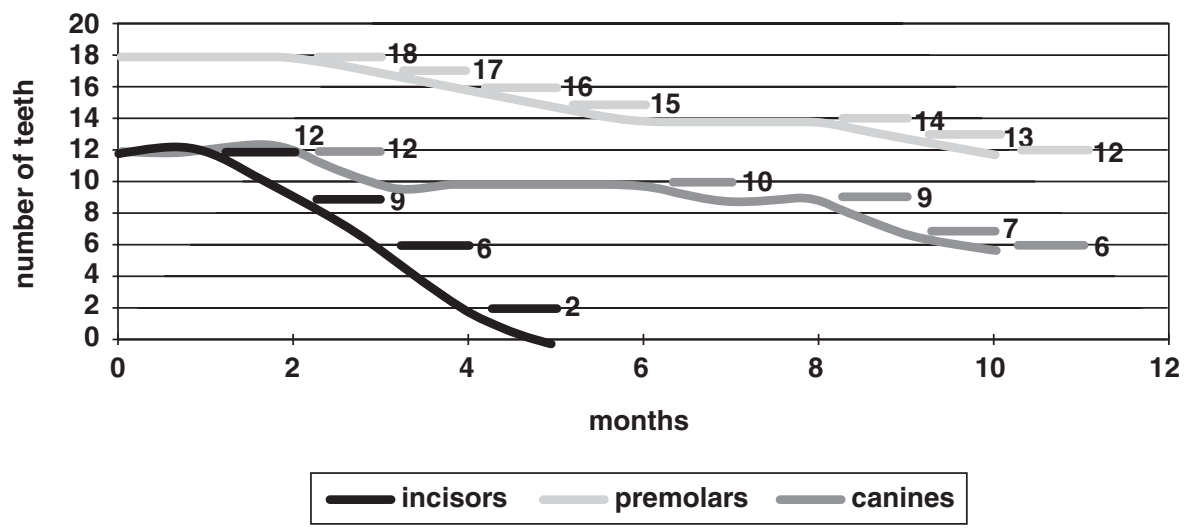

Fig. 2. Survival of pulp in groups of teeth - Group 1

The difference between groups in premolar viable pulps involved only 3 teeth (16.6\%). In the case of canine dental pulps, Group 1 dogs showed much higher viability $(6$ teeth $-50 \%)$ than those in Group 2 (2 teeth - 16\%). None of the incisor dental pulps remained viable for 10 months.

After ten months of study 12 premolar pulps (66.6\%) were vital in Group 1 and 9 (50\%) in Group 2.

The vitality of incisor dental pulps in the first group of dogs decreased continuously during the first 5 months of study. On the other hand, all incisor dental pulps of the dogs in Group 2 necrotized within the first month of study. 


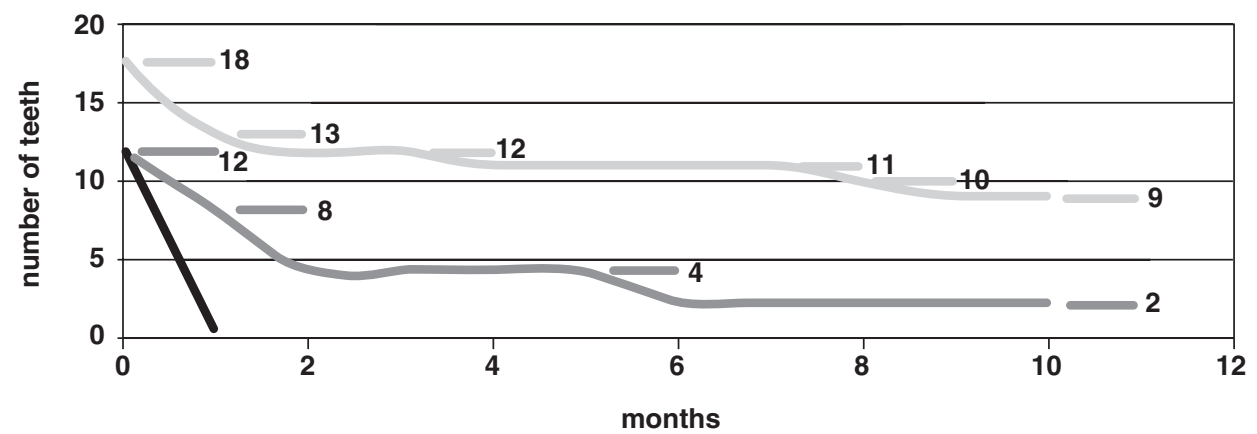

incisors premolars canines

Fig. 3. Survival of pulp in groups of teeth - Group 2

Dentin deposition in fractured teeth

The initial mean width of the root canal differed between the individual tooth groups and also between the two groups of dogs.

The initial mean width of incisor root canals in Group 1 of dogs was $43 \%$. In the incisors, which remained viable for 4 months, the root canal width decreased by about $9 \%$ to the final $34 \%$. In Group 2 of dogs the initial width of incisor root canals (24\%) was not reduced as all dental pulps necrotized during the first month after the fracture (Fig. 4).

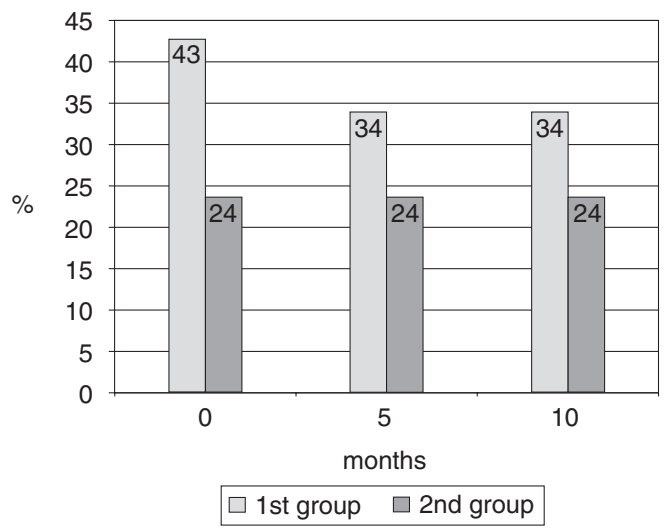

Fig. 4. Dentin production in fractured incisors

The initial mean width of canine root canals was 58\% in Group 1, and $27 \%$ in Group 2 (Fig. 5). During the first 5 months of study, the root canal width of the dogs in Group 1 decreased by about $19 \%$ and during the subsequent 5 months by additional $18 \%$ to the final width of $21 \%$. The total difference in the canine root canal between the initial and the final width was $37 \%$ in this group.

In Group 2, i.e. in dogs with the initial root canal width of $27 \%$, the total decrease was only $6 \%$, divided equally between the two five months study periods. The final canine root canal width in this group was $21 \%$. 


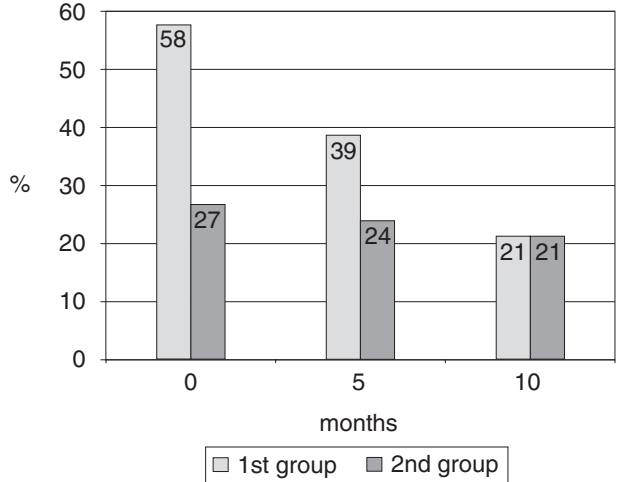

Fig. 5. Dentin production in fractured canines

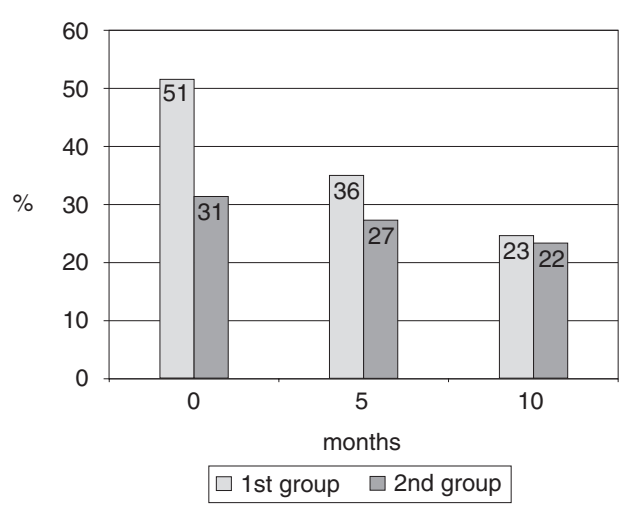

Fig. 6. Dentin production in fractured premolars

Dentin deposition in the premolars resembled that found in canines (Fig. 6). The width of the root canal decreased from $51 \%$ to $23 \%$ in Group 1, and from $31 \%$ to $22 \%$ in Group 2 . The decrease in the width over the five-month period amounted to approximately $14 \%$ in Group 1 and $4 \%$ in Group 2.

Eighteen months after the beginning of study eight teeth $(9.75 \%)$ in both groups of dogs showed clinical and radiological signs of vitality. Besides that in two of these teeth the pulp cavity was completely closed by tertiary dentin.

\section{Discussion}

This study showed that the viability of teeth in the dogs of Group 1 was significantly higher as confirmed by F-test $(P \leq 0.01)$. The dentin deposition was also higher in this group. This result was expected as the intensity of dentin production decreases physiologically with tooth ageing. An important clinical sign was the rate of dentin deposition. The teeth that remained viable for 10 months in both groups of dogs had the same width of root canal despite the obvious difference in the age of dogs included. These results may reflect either an increased dentin deposition in Group 1 or its decreased deposition in Group 2. In our opinion, it was the higher dentin production in Group 1 as a result of defensive mechanisms. This is an area of continuing research. In future, in healing of teeth it may even be possible to use transplantation of odontoblasts or dental mesenchymal cells, similar to chondrocyte transplanation as already carried out experimentally in animals (Gál et al. 2002).

Our study also confirmed the influence of location of teeth in the mouth cavity on their viability. The more caudal the location of teeth, the higher viability they have shown. We ascribe this to the beneficial influence of saliva and better protection of teeth situated more caudally.

Permanent exposure of dental pulp to oral microflora suggests that its action has no limiting effect on the viability of dental pulp in dogs in this study. The decisive role may probably be ascribed to the immediate contact with the external environment and decreased washing of the exposed dental pulp with saliva. The production of dentin continued, and in unique cases dentin closed completely the pulp cavity in the fracture line. The presented results point to the ability of odontoblasts to produce secondary dentin despite prolonged exposure of the dental pulp. 
The degree of the concussion shock seems to be one of the most important factors affecting the vitality of teeth after fracture. Our study confirmed that the teeth subjected to fracture while avoiding concussion shock were able to retain their vitality longer in comparison with clinical cases despite exposure of dental pulp to oral microorganisms (Capík et al. 2000). Altogether $47.6 \%$ of dental pulps were vital after five months of study and $34.5 \%$ dental pulps maintained their vitality during ten months. These results confirm the ability of dental pulp to survive for a relatively long time and to produce dentin.

In practice, the majority of dogs with fractured teeth are not presented in the first hours after trauma. Based on our present results we recommend administration of non-steroid antiinflammatory drugs to decrease pain and severe initial inflammatory reaction during the acute stage and regular physical examinations of dental pulp to asses its health. In fractured teeth with surviving dental pulp, standard endodontic therapy is indicated at the age of two years of the dog. At this age sufficiently thick dentinal walls should be present. Standard endodontic therapy is also the treatment of choice in the case of dental pulp necrobiosis.

The results obtained indicate a more pronounced effect of the age of dogs, degree of trauma and tooth localization on viability of the pulp than the effect of pulp contamination. Furthermore, it is not possible to exclude the influence of behavioural factors in animals used in the study.

\section{Vitalita zubnej drene a depozícia dentínu do poranených nedospelých zubov u psov}

Táto štúdia bola vypracovaná za účelom zistenia reakcie zubnej drene po fraktúrach zubov počas prvých dvoch rokov veku, v dobe najväčšej produkcie dentinu. Účelom štúdie bolo porovnat schopnosti prežívania zubnej drene a pokračovania produkcie dentínu po hlavný čas maturácie.

V tejto štúdií sme použili 12 psov. Prvú skupinu tvorilo 6 psov vo veku $12 \pm 1$ mesiac. Druhú skupinu tvorilo 6 psov vo veku $20 \pm 1$ mesiac. Všetky zákroky boli prevedené v anestézii. U každého psa bolo $\mathrm{v}$ anestéze zlomených sedem zubov - dva rezáky, dva špičiaky a tri premoláre (tretí, štvrtý horný a tretí dolný). Zubná dreň bola získaná amputáciou v koronárnej tretine koruniek za použitia vysokofrekvenčnej zubnej vŕtačky a extrakciou pinzetou tak, aby nebola poškodená. Klinické a rentgenologické vyšetrenia zubov sa opakovali v mesačných intervaloch po dobu jedného roka. Všetky rentgenogramy zhotovené $\mathrm{v}$ prvom, piatom a desiatom mesiaci štúdie boli spracované a zhodnotené počítačovým programom. Výsledky ukázali významné rozdiely (F-test, $P \leq 0,01) \mathrm{v}$ životnosti zubnej drene s relatívne malou rozdielnostou vo veku. Na konci štúdie zuby, ktoré ostali životaschopné po desat mesiacov u obidvoch skupín psov, mali rovnakú šírku koreňových kanálikov napriek rozdielom vo veku psov a povodnej šírke koreňových kanálov. Životaschopnosṫ zubnej drene sa zdá byt ovplyvnená najmä stupňom šoku spôsobeného poranením a lokalizáciou zubov v ústnej dutine.

Acknowledgements

This study was supported by Scientific Grant Agency of Ministry of Education of the Slovak Republic and Slovak Academy of Sciences No. 1/7039/20.

\section{References}

BARANYIOVÁ, E, HOLUB, A, MARTINÍKOVÁ, M, NEČAS, A, ZATLOUKAL, J 2003: Epidemiology of intraspecies bite wounds in dogs in the Czech Republic. Acta Vet Brno 72: 55-62

BÖVIER, M, JOFFRE, A, MAGLOIRE, M 1990: In vitro mineralization of a three-dimensional collagen matrix by human dental pulp cells in the presence of chondroitin sulfate. Arch Oral Biol 35: 301-309

CAPÍK, I, LEDECKÝ, V, ŠEVČÍK, A 2000: Tooth fracture evaluation and endodontic treatment in dogs. Acta Vet Brno 69: 115-122 
COX, CF, BERGENHOLTZ, G 1986: Healing sequence in capped inflamed pulps of Rhesus monkeys (Macaca mulatta). Int Endodon J 19: 113-120

CVEK, M 1982: Pulp reactions to exposure after experimental crown fracture or grinding in adult monkeys. J Endodon 8: 391

DUELL, RC 1995: Emergency Dental Care, Ed Palace, Williams \& Wilkins, Philadelphia, p. 67

FITZGERALD, M, CHIEGO, DJ, HEYS, DR 1990: Autoradiographic analysis of odontoblast replacement following pulp exposure in primate teeth. Arch Oral Biol 35: 707-715

GÁL, P, NEČAS, A, ADLER, J, TEYSCHL, O, FABIÁN, P, BIBROVÁ, Š 2002: Transplantation of the autogenous chondrocyte graft to physiological defects: an experimental study in pigs. Acta Vet Brno 71: 327332

HEIDE, S 1980: Pulp reactions to exposure for 4, 24 and 168 hours. J Dent Res 59: 1910-

HEIDE, S, KEREKES, K 1986: Delayed pulpotomy in permanent incisors of monkeys, Int J Endodon 19: 78-

HEIDE, S, KEREKES, K 1987: Delayed direct pulp capping in permanent incisors of monkeys. Int J Endodon 20: 65

HERITIER, M, DANGLETERRE, M, BAILLIEZ, Y 1989: Ultrastructure of a new generation of odontoblasts in grafted coronal tissues of mouse molar tooth germs. Arch Oral Biol 34: 875-883

KAKEHASHI, S, STANLEY, HR, FITZGERALD, RJ 1965: The effects of surgical exposures of dental pulps in germ-free conventional laboratory rats. Oral Surg Oral Med Oral Pathol 20: 340-349

LANGELAND, K, DOWDEN, WE, TRONSTAD, L, LANGELAND, LK 1973: Human pulp changes of iatrogenic origin. In: Siskin M (Ed.): The Biology of Human Dental Pulp. Mosby: St Louis, pp.

NAKASHIMA, M 1991: Establishment of primary cultures of pulp cells from bovine permanent incisors. Arch Oral Biol 36: 655-663

RUCH, JV 1985: Odontoblast differentiation and the formation of the odontoblast layer. J Dent Res 64: 489-498

TRONSTAD, L, MJÖR, IA 1972: Capping of the inflamed pulp. Oral Surg Oral Med Oral Pathol 34: 477-85

WIGGS, RB, LOBPRISE, HB 1997: Veterinary Dentistry: Principles and Practise, Eds Wiggs \& Lobprise, Lippincott-Raven, Philadelphia 